\title{
The Seven Ages of Meeting Attendees
}

\section{All the world's a stage,}

And all the men and women merely players:

They have their exits and their entrances;

And one man in his time plays many parts,

His acts being seven ages.

\section{Shakespeare, As You Like It, Act II, Scene vii}

An MRS Meeting is a play with many acts (symposia) and scenes (sessions). Each attendee plays a particular role, but all take a wide range of parts as their careers develop. Doubtless you will find yourself described below and although you may eventually play every part, you will be grateful that you do not fill those roles for which (as yet) you are not cast.

\section{At first the infant,}

Merwling and puking in the nurse's arms.

First, the Graduate Student, by day never straying far from advisor's grasp; taking full and detailed notes at every talk. By night a-party, coping variously with unaccustomed quantities of beer.

\section{And then the whining schoolboy, with his satchel, \\ And shining morning face, creeping like snail \\ Unwillingly to school.}

Then the Post-Doc with laptop and intense demeanor. Shunning talks by students, but pursuing the noted and those with jobs to offer.

\section{And then the lover,}

Sighing like furnace, with a woful ballad

Made to his mistress' eyebrow.

And then the fresh-faced and freshly-hired professional, breathlessly explaining how he'd change the world, if only he could seduce some manager of grants or contracts to incline an unbiased eye over his proposal.

\section{Then a soldier,}

Full of strange oaths, and bearded like the pard,

Jealous in honour, sudden and quick in quarrel,

Seeking the bubble reputation

Even in the cannon's mouth.

Then tenured and liveried in institutional pride, our hero struts to the podium in the face of all rivals, giving talks replete with obscure references and coining phrases to perpetuate and glorify his name. His responses to questions are all contrived to debase the questioner's expertise.
And then the justice,

In fair round belly with good capon lin'd,

With eyes severe, and beard of formal cut,

Full of wise saws and modern instances;

And so he plays his part.

And then, the Society Hack attending not the technical sessions, but all the breakfast, lunch, and dinner-serving committee meetings. Judging the worthiness of the good and the great for prizes and honors, he maintains a studied silence on Society matters and deflects all questions with elliptical answers and philosophical generalizations. $\mathrm{He}$ is ever conscious of the dignity of his position.

The sixth age shifts

Into the lean and slipper'd pantaloon,

With spectacles on nose and pouch on side,

His youthful hose well sav'd a world too wide

For his shrunk shank; and his big manly voice,

Turning again towards childish treble, pipes

And whistles in his sound.

The sixth age is that of the Former Officer of the Society, with no great role to play. His dress has changed from stylish to comfortable, with relaxed-fit slacks and softsoled shoes to make the long conference day more bearable. His pockets are laden with bifocals and an empty PDA. He returns now to the technical sessions, but no longer engages in debate or discussion. He rides elevators patiently without concern for the schedule, where once he rushed up and down the stairs to catch every talk.

\section{Last scene of all,}

That ends this strange eventful history,

Is second childishness, and mere oblivion,

Sans teeth, sans eyes, sans taste, sans everything.

The role that crowns a successful career is the Elder Statesman, prowling the larger and emptier lecture halls, and giving reminiscences as invited lectures. His curiosity is rekindled and refrains his graduate school days, except that others now must listen politely and try to answer his questions. With failing health and faltering senses, his remarks are often taken for trivialities or expressions of unfamiliarity with the burgeoning field, and he is tolerated, but ultimately considered irrelevant-at least by those who fail to understand the power of a simple question well-posed, and who fail to see their own mortality.

May you all live so long, AlEx KING (of the sixth age) 